\title{
Some considerations about the use and applicability of preference-based health-related quality of life measures to survivors of cancer in childhood and adolescence in developing countries
}

\author{
Claudia Cristina de Aguiar Pereira*
}

\begin{abstract}
Measures of health-related quality of life (HRQoL) have become widely available in developed countries such as the United States, Canada and the United Kingdom. Such measures, instruments or questionnaires need to undergo translation processes, validation and cultural adaptation in order to be used in other countries and in other languages. The utilization of measures developed in settings other than the originating ones poses several challenges, including the appropriateness of the translation and of the cross-cultural adaptation and adequate validation process. Preference-based or preference-weighted utilities for health states have an important role in measurement and in economic evaluation regarding a wide range of conditions, such as childhood cancer and survivorship. Some attempts have been made to create and apply preference-based HRQoL indexes to young populations, such as children, adolescents and young adults. Use of proxy respondents is an issue for studying HRQoL in these groups, especially children. This review aims at providing a critical evaluation of the use of preferencebased HRQoL measures in developing countries, focusing on the Health Utilities Index, Mark 2 and Mark 3, commonly called HUI2 and HUI3, and their application to survivors of childhood cancer in Latin America. The process researchers undertake, especially in regards to the use of already translated instruments is discussed. The appropriateness of the instruments is also assessed and focus is on the attributes of the instrument and the population, the cultural aspects and the use of proxy respondents. Finally, the adequateness of other commonly used preference-based instruments for childhood cancer is discussed. This critical assessment could benefit future work in the area of health-related quality of life, especially guiding those interested in the trans-cultural use of existing generic preference-based HRQoL instruments.
\end{abstract}

Keywords: HUI2. HUI3. Latin America. Cross-cultural validation. Childhood cancer. Proxy-respondents.

\section{Introduction}

The measurement of health-related quality of life (HRQoL) has become a growing field of research. With many developments that are informed by areas such as population health sciences, psychometrics and economics, a great number of indexes or instruments have become available. As a result, one must carefully choose the instrument before

\footnotetext{
* Pos-doutoranda na Johns Hopkins University, Bloomberg School of Public Health, Departament of Population, Family and Reproductive Health. Doutora em Population Health, University of Wisconsin - Madison. Mestre em Demografia pelo Centro de Desenvolvimento e Planejamento Regional - Cedeplar da Universidade Federal de Minas Gerais.
} 
utilization in different populations. This also holds true for the application of these instruments in countries different from the ones where these instruments were originally developed.

HRQoL instruments can be broadly classified into two types: generic and disease or condition-specific. Generic measures are comprised of different health domains and have the advantage of allowing comparisons across different demographic or clinical populations. Disease-specific instruments are designed to assess the quality of life associated with a particular condition or disease (McDOWELL, 2006).

In recent decades, utility assessment of health states has become increasingly important, especially due its usefulness in economic evaluation of interventions, such as cost-utility analysis (WILHELMINE; ROBINSON; LAWRENCE, 2006). This process involves selecting a community sample, in which participants indicate preferences for health states and give a weight to these health states, and a utility score is then assigned in a conventional scale in which death $=0$ and perfect or full health $=1$. The utility score is usually incorporated into a quality-adjusted life year (QALY), which combines into a single index, quantity and quality of life (GOLD et al., 1996). Utilities can be assessed directly through some techniques, such as the standard gamble (SG), time trade-off (TTO), Visual Analogue Scale (VAS), which are exercises to assess preferences for different health states. A detailed explanation of these techniques can be found in the book by Gold et al., 1996. Direct techniques are very time consuming and complex, so a more recent alternative has been to use utilities obtained indirectly using generic preference-based health-related quality of life (HRQoL) instruments. Indirect methods bypass the direct methods by using prescored multi-attribute systems classification systems, commonly called generic preference-based health-related quality of life (HRQoL) instruments. The most commonly used are: the Euroqol - EQ-5D, developed in Western Europe, the Quality of Well-Being Scale-self-administered
(QWB-SA) created in the United States, the SF-6D, introduced by researchers from the United Kingdom, and is obtained from the widely used SF-36 or SF-12 systems; and the Health Utilities Index Mark 2 (HUI2) and Mark 3 (HUI3) developed in Canada. These five generic preference-based healthrelated quality of life (HRQoL) measures are quite different from each other, as they are created using distinct methodologies and are comprised of different health domains or attributes, thus leading to particular strengths and weaknesses, so results may differ depending on which one is chosen. They have also been used cross-culturally (FU et al., 2006; SHIMODA et al., 2005; BARR et al., 2001). This paper aims to provide an overview of generic preferencebased instruments used to study quality of life among childhood and adolescence cancer survivors and to discuss the issues with translated versions, cultural diversity, validation and adaptation as well as the aspects related to using proxy respondents.

\section{Overview of HUI-2 and HUI-3 and use for childhood and adolescence cancer survivors}

Defining the appropriateness of a HRQoL measure for a study can be a considerable challenge, not only because of the amount of options currently available, but also because the task of choosing the appropriate instrument for a study has to be carefully guided by the overall and specific goals of the proposed investigation, including the amount of time an instrument requires to be answered, an issue the literature calls response burden (EISER; MORSE, 2001b). With respect to generic measures, whether preference-based or not, researchers need to be aware that given their comprehensiveness, they may not be responsive to small changes in conditions, especially regarding children. This could result in overlooking relevant aspects of patients' lives related to the specific condition under study (BRYAN; LONGWORTH, 2005). The Health Utilities Index (HUI) family of preference-based indexes was developed for measuring 
the overall health status and HRQoL of individuals, clinical groups, and general populations (FEENEY; TORRANCE; FURLONG, 1996). Both the Health Utilities Index Mark 2 (HUI2) and Mark 3 (HUI3) are classified as generic multi-attribute preference-based measures of health status and HRQoL. The HUI2 consists of seven attributes of health status: sensation, mobility, emotion, cognition, self-care, pain and fertility (optional domain). Moreover, the HUI3 consists of eight attributes of health status: vision, hearing, speech, ambulation, dexterity, emotion, cognition, and pain with five or six levels per attribute or domain, varying from highly impaired to normal (MADDIGAN et al., 2003). Altogether the HUI2 and HUI3 are considered independent but complementary systems, which together describe almost 1 million unique health states to measure the HRQoL (EISER; MORSE, 2001b). Studies claim the appropriateness of the HUI2 and HUI3, as useful preference-based measures of health status and HRQoL in children surviving cancer (BARR et al., 1999), as well as in adolescents who survived childhood cancer (GRANT et al., 2006), and for young adults, under the age of 30 (CARDARELLI et al., 2006), given that the survivors can have a wide age range, like for example, from 3.4 to 25.8 years in the study for survivors in Central America (FU et al., 2006). The HUI is not recommended for children under the age of five, and many studies do not strictly follow that recommendation (FU et al., 2006). It is worthwhile pointing out that the HUI2 has been widely used since its beginning in studies about survivors of childhood cancer (FEENEY; TORRANCE; FURLONG, 1996). Considering the historical use of the HUI2 and HUI3 for the cancer survivors, researchers (FU et al., 2006) argue the use is justifiable and claim the necessity of assessing the HRQoL of survivors of childhood cancer in a preference-based manner, as survivorship has increased in developing countries, following what has been observed in developed countries. Nevertheless, even with the evidence of extensive historical use of the HUI2 and
HUI3 for childhood cancer survivors, it is still important to assess whether their use is actually adequate, raising the question of whether the HUI2 and HUI3 are actually children-friendly instruments. The use of instruments for children should have special focus in the suitability, length, complexity, as to match skills of children and young adults (EISER; MORSE, 2001a). Furthermore, researchers should be concerned with the illiteracy rates of both children, adolescents and adults, whether parents or not in developing countries. This is an issue to have in mind even when interviewers administer the questionnaires. The correct understanding of what is being asked is of vital importance. Moreover, response burden is another concern. Questionnaires can be lengthy. For instance, in the study by Fu and colleagues (2006) they varied in length for patients (43 items), parents (46 items) and physician (15 - self-completed items). These differences raise questions regarding comparability among the three types of respondents. Also, asking a 43-item questionnaire to a child can be considered burdensome, and also for the parent with an even longer questionnaire.

One of the characteristics of the HUI2 and HUI3 is that they are designed to measure functional capacity, not performance (FEENEY; TORRANCE; FURLONG, 1996). Capacity could be defined as the ability to perform at a given level. Altogether, capacity, opportunity and preferences could be considered the determinants of overall performance. The fact that these participants have undergone extreme treatments such as chemotherapy and surgery is likely to have affected the child/adolescent/young adult's personal preferences and perhaps opportunities, for example, by having missed school to undergo treatment or losing contact with friends due to stays at the hospitals. The fact that HUI2 and HUI3 target capacity only, might result in leaving out some important pieces of the puzzle, like for instance, those related to social interactions, disruptions in childhood and emotional aspects that are beyond the ones addressed by these two generic questionnaires. 


\section{Other preference-based instruments appropriateness for this type of research}

Throughout the quality of life literature it is possible to find considerable amounts of disagreement concerning the preferred generic utility-based measure of HRQoL (BRYAN; LONGWORTH, 2005; BRYAN; LONGWORTH, 2003). The development of the most recent measure, the SF-6D, which is derived from either the Short Form (SF)$36 \mathrm{v} 2$, or the SF-12, has generated quite an amount of discussion in several peerreviewed papers, mostly authored partially by their developers (WEE et al., 2007). For instance, similarities between the SF-6D and EQ-5D have been highlighted at the same time that studies have reported quite a variation when comparing results that used both instruments (PETROU; HOCKLEY, 2005). In part differences in results arise from the different health states and health domains described in different preferencebased instruments and from different valuations that are placed on similar health states (BRYAN; LONGWORTH, 2005). As the SF-6D has been reported to not well describe health states at the lower end of the utility scale (BRYAN; LONGWORTH, 2003), it may not be most appropriate instrument for cancer research. Furthermore, the SF-6D does not provide specific recommendations regarding its use for children/teenagers (EISER; MORSE, 2001a). Similar issues revolve the use of the EQ-5D and QWB, given the peculiarities of sick populations.

As previously discussed, the $\mathrm{HUI} 2$ and $\mathrm{HUI} 3$ are not disadvantage-free, but if the researcher wants to utilize a generic preference-based HRQoL, they are options to be considered. Another advantage would be the possibility of comparability with previous studies that also used the HUI2 and HUI3 for the same or similar health conditions.

\section{Issues regarding the translation, validation, and cultural differences and adaptation}

Whenever an instrument is used in a different language, the degree to which it is equivalent to the original intent is of fundamental importance. A potential threat to validity in this context stems from whether a specific item, a single-attribute or health domain and or the entire instrument differ systematically across cultural or geographic settings. Extreme caution needs to be exercised when undertaking linguistic modifications to established instruments, for instance, from English to Portuguese or Spanish, as the process may result in loss of the ability to detect important information and reduce the comparability of results between studies, as has already happened with studies using the HUI2 and HUI3, between the Canadian original version to British English (GLASER et al., 1999). It is usually recommended that careful crosscultural adaptation, such as translation; back-translations and expert consensus take place (ACQUADRO et al., 2008).

Another concern is that even when different countries have the same language, there are within-country language specificities and cultural differences that may affect the use elsewhere. For example, $\mathrm{Fu}$ and colleagues (2006) used an already available translation of the HUI2 and HUI3 into Spanish and culturally adapted to Argentinean children, for children in Central America, which according to the HUI and Argentinean research groups, were adequate for use with the groups tested in a pilot survey of survivors of childhood cancer in Argentina (SZECKET et al., 1999). However, the original adaptation work did not mention any aspects about the suitability and adequacy for other Spanish-speaking countries. It is recommended for research of this nature to include a discussion regarding the adequacy of the version being used when it is different from the country to which it was adapted for. Latin American Spanishspeaking countries are very diverse, not only culturally, but also there are linguistic nuances and specific characteristics of the language in each country that cannot be overlooked. The same could be said about Portuguese-speaking countries, francophone and others. It is indispensable that researchers be aware of the cultural and ethnic biases that could result from use of 
improper instrument, thus compromising study findings.

In like manner, the utility measures used for the health states in the HUI2 and HUI3 are based in the Canadian population, more specifically of Hamilton, Ontario (FEENEY et al., 2002), and although it is said that using the same originating weights may not be so problematic, as there is stability of preferences for generic health states across different groups of people when measured with the same instrument (GOLD et al., 1996), this aspect should not be overlooked. Efforts ought to be made to estimate the utility scores in Latin American populations, for more appropriate community-weighted preferences. For example, in a comparison made for the population of Spain to the population of Canada, it was found that the Spanish and Canadian utility function differed significantly: 0.07 points, $p<0.001$, thus suggesting the need of using the specific function for each population (RUIZ et al., 2006).

\section{Issues regarding proxy respondents and other recommendations}

In order to assess the health of adults, especially of those who are not cognitively impaired, self-report is usually the best method of assessing HRQoL. In the case of children, depending on their age, it is preferable that parents respond to the questionnaire on behalf of the child, as a proxy-respondent (GLASER et al., 1997) since some of the concepts, language, terminology and health domains assessed may not be adequately understood by individuals during the childhood stage of development. In the case of very young children and infants some of the domains and attributes assessed in these instruments may be too hard to be understood or captured even for parents answering in lieu of the child, like for example ability to read newspapers in the vision attribute of the HUI3, simply because some of the tasks are not performed by very young individuals. The HUI System recommends against the use of proxy respondents for children older than eight years of age. The system is not recommended for children below the age of five. For children between the ages of five and eight, the self-assessment is not recommended, whereas the use of a proxy respondent is considered the gold standard (HORSMAN et al., 2003). Nevertheless, the use of parents as proxy respondents can be problematic in many ways. For example, high discrepancy among scores reported by different respondents has been identified. In studies that look at the interrater reliability between patients, parents and physicians, the intra-class correlation tends to be low, usually lower than 0.5 . According to other studies that use $\mathrm{HUI} 2$ and HUI3, taking the child's assessment as the reference, the parents tend to underestimate the health status (LE GALES et al., 1999). Parents and patients agree more on observable functioning aspects and less in non-observable functioning, as it would be expected. This issue is of particular importance to adolescents who are survivors of childhood disease. As they grow up and reach adolescence free of the cancer, it is likely that they would not share as much of their nonobservable emotional or social issues with other individuals, including parents. The impact of interviewing patients with different surviving times/proximity to cure could also impact results of clinical studies. A study reported that agreement was better between children and parents of sick children than of healthy children (EISER; MORSE, 2001a). Despite these discrepancy issues, there are still strong arguments for obtaining information from both parents and children whenever possible, and not just information from the parent (EISER; MORSE, 2001b).

Another recommendation for studies in this area of research is the comparison of results to the ones of population-based on large samples and compared to population controls (POGANY et al., 2006). This is related to a good sampling strategy in order to avoid the use of a convenience sample. Content validity, criterion validity, and construct validity should be reported in original research of translation and crosscultural validation. 


\section{Final remarks and conclusion}

This review has highlighted the main concerns when addressing the suitability of a generic preference-based instrument, with emphasis on the use for childhood and adolescence cancer survivorship and quality of life. Preference-based healthrelated quality of life measures need to be further developed in coming years, so as to better capture aspects of quality of life that are unique to children, and or very young children. Despite this necessity, translations and cross-cultural adaptations of the instruments that are currently available should be done using the highest standards, and researchers need to exert caution when using these measures, first by being aware of how the adaptation was done and second by evaluating the aspects of quality of life that are relevant to the population under study in order to choose the most appropriate instrument.

\section{References}

ACQUADRO, C.; CONWAY,K.; HAREENDRAN, A., AARONSON, N. European Regulatory Issues and Quality of Life Assessment (ERIQA) Group. Literature review of methods to translate health-related quality of life questionnaires for use in multinational clinical trials. Value in Health, Lawrenceville, 11(3): 509-521, 2008.

BARR, R.D.; GONZALEZ, A.; LONGCHONG, M.; FURLONG, W.; VIZCAINO, M.P.; HORSMAN, J.; FU, L.; CASTILLO, L. Health status and health-related quality of life in survivors of cancer in childhood in Latin America: a MISPHO feasibility study. International Journal of Oncology, Athens, 19(2): 413-21, 2001.

BARR, R.D.; SIMPSON, T.; WHITTON, A.; RUSH, B.; FURLONG, W.; FEENY, D.H. Health-related quality of life in survivors of tumours of the central nervous system in childhood - a preference-based approach to measurement in a cross-sectional study. European Journal of Cancer, Edinburgh, 5(2): 248-55, 1999.
The problems that may emerge from using a preference-based instrument that has not been carefully been translated and adapted for (a) different population(s) than the one it was originally designated for were also discussed. In the coming years, it is expected that a large number of crosslanguage and cross-cultural adaptations of health instruments be made, preferencebased or not, and for both generic and disease-specific, due to their usefulness to summarize population health, monitor health changes, and increasing use of preferencebased ones in economic evaluation of health interventions.

The review also emphasizes the aspects that should not be overlooked in future studies utilizing the HUI2 and HUI3 in different cultures. It is suggested that researchers exercise caution when selecting and using a preference-based generic HRQoL measure, especially in regards to study goals and context.

BRYAN, S.; LONGWORTH, L. Measuring health-related utility: why the disparity between EQ-5D and SF-6D? European Journal of Health Economics, Hannover, 6(3): 253-60, 2005.

An empirical comparison of EQ5D and SF-6D in liver transplant patients. Health Economics, New York, 12(12): 1061-7, 2003.

CARDARELLI, C.; CEREDA, C.; MASIERO, L.; VISCARDI, E; FAGGIN, R.; LAVERDA, A.; BISOGNO, G.; PERILONGO, G. Evaluation of health status and health-related quality of life in a cohort of Italian children following treatment for a primary brain tumor. Pediatric Blood \& Cancer, Baltimore, 46(5): 637-44, 2006.

EISER, C.; MORSE, R. Can parents rate their child's health-related quality of life? Results of a systematic review. Quality of Life Research, Bethesda, 10(4): 347-57, 2001.

Quality-of-life measures in chronic diseases of childhood. Health Technology 
Assessment, Southampton, 5(4): 1-157, 2001.

FEENY, D.; FURLONG, W.; TORRANCE, G.; GOLDSMITH, C.; ZHU, Z.; DEPAUW, S.; DENTON, M.; BOYLE, M. Multiattribute and single-attribute utility functions for the health utilities index mark 3 system. Medical Care, Philadelphia, 40 (2): 113-28, 2002.

FEENEY, D.H.; TORRANCE, G.W.; FURLONG, W.J. Chapter 26 - Health Utility Index. In: SPILKER, B (Ed.). Quality of life and pharmacoeconomics in clinical trials. Second Edition. Lippincott-Raven Publishers, Philadelphia, 1996.

FU, L.; TALSMA, D.; BAEZ, F.; BONILLA, M.; MORENO, B.; AH-CHU, M.; PENA, A.; FURLONG, W.; BARR, R.D. Measurement of health-related quality of life in survivors of cancer in childhood in Central America: feasibility, reliability, and validity. Journal of Pediatric Hematology/Oncology, Philadelphia, 28(6): 331-41, 2006.

GLASER, A.W.; DAVIES, K.; WALKER, D.; BRAZIER, D. Influence of proxy respondents and mode of administration on health status assessment following central nervous system tumours in childhood. Quality of Life Research, Bethesda, 6(1): 43-53, 1997.

GLASER, A.W.; FURLONG, W.; WALKER, D.A.; FIELDING, K.; DAVIES, K; FEENY, D.H.; BARR, R.D. Applicability of the Health Utilities Index to a population of childhood survivors of central nervous system tumours in the U.K. European Journal of Cancer, Edinburgh, 35(2): 256-61, 1999.

GOLD, M.R.; SIEGEL, J.E.; RUSSELL, L.B.; WEINSTEIN, M.C. Cost-effectiveness in health and medicine. New York: Oxford University Press, 1996.

GRANT, J.; CRANSTON, A.; HORSMAN, J., FURLONG, W.; BARR, N.; FINDLAY, S.; BARR, R. Health status and health-related quality of life in adolescent survivors of cancer in childhood. Journal of Adolescent Health, San Francisco, 38(5): 504-10, 2006.

HORSMAN, J.; FURLONG, W.; FEENY, D.; TORRANCE, G. The Health Utilities Index (HUI): concepts, measurement, properties and applications. Health and Quality of Life Outcomes, London, 1(54):1-13, 2003.

LE GALES, C.; COSTET, N.; GENTET, J.C.; KALIFA, C.; FRAPPAZ, D.; EDAN, C.; SARIBAN, E.; PLANTAZ, D.; DOZ, F. Cross-cultural adaptation of a health status classification system in children with cancer. First results of the French adaptation of the Health Utilities Index Marks 2 and 3. International Journal of Cancer, Heidelberg, 12 (Suppl.): 112-8, 1999.

MADDIGAN, S.L.; FEENY, D.H.; JOHNSON, J.A.; DOVE INVESTIGATORS. A comparison of the health utilities indices Mark 2 and Mark 3 in type 2 diabetes. Medical Decision Making, Portland, 23(6): 489-501, 2003.

MCDOWELL, I. General health status and quality of life. In: McDOWELL, I. Measuring health: a guide to rating scales and questionnaires. Third Edition. New York: Oxford University Press, 2006.

PETROU, S.; HOCKLEY, C. An investigation into the empirical validity of the EQ-5D and SF-6D based on hypothetical preferences in a general population. Health Economics, New York, 14(11): 1169-89, 2005.

POGANY, L.; BARR, R.D.; SHAW, A.; SPEECHLEY, K.N.; BARRERA, M.; MAUNSELL, E. Health status in survivors of cancer in childhood and adolescence. Quality of Life Research, Bethesda, 15(1): 143-57, 2006.

RUIZ, M.; REJAS, J.; SOTO, J.; PARDO, A.; REBOLLO, I. Adaptation and validation of the Health Utilities Index Mark 3 into Spanish and correction norms for Spanish population. Medicina Clinica, Barcelona, 120(3): 8996, 2003.

SHIMODA, S.; DE CAMARGO, B.; HORSMAN, J.; FURLONG, W.; LOPES, L.F.; SEBER, A.; BARR, R.D. Translation and cultural adaptation of Health Utilities Index (HUI) Mark 2 (HUI2) and Mark 3 (HUI3) with application to survivors of childhood cancer in Brazil. Quality of Life Research, Bethesda, 14(5): 1407-12, 2005.

SZECKET, N.; MEDIN, G.; FURLONG, W.J.; FEENY, D.H.; BARR, R.D.; DEPAUW, S. 
Preliminary translation and cultural adaptation of Health Utilities Index questionnaires for application in Argentina. International Journal of Cancer, Heidelberg, 12 (Suppl.): 119-24, 1999.

WEE, H.; MACHIN, D.; LOKE, W.; LI, S.; CHEUNG, Y.; LUO, N.; FEENY, D.; FONG, $\mathrm{K}$; THUMBOO, J. Assessing differences in utility scores: a comparison of four widely used preference-based instruments. Value in Health, Lawrenceville, 10(4): 256-65, 2007.

WILHELMINE, M.; ROBINSON, L.A.; LAWRENCE, R.S. (eds.). Valuing Health for Regulatory Cost-Effectiveness Analysis. Washington: The National Academy Press, 2006. Available at: <http://books.nap.edu/ openbook. php?isbn $=0309100771>$. Last access on: September 18, 2009.

\section{Resumo}

Algumas considerações acerca do uso e aplicação de medidas de qualidade de vida associada à saúde, com ênfase em estudos sobre sobreviventes de câncer na infância e adolescência em países em desenvolvimento

Instrumentos para medir a qualidade de vida associada à saúde vêm se tornando cada vez mais usados em países desenvolvidos, como Estados Unidos, Canadá e Reino Unido. Essas medidas devem passar por processos de tradução, validação e adaptação cultural antes de serem usadas em países e/ou línguas, que não os de origem. A utilização de instrumentos desenvolvidos em outros contextos culturais apresenta vários desafios, tais como a propriedade da tradução, adequação da adaptação cultural, bem como satisfatório processo de validação. Preferências por estados de saúde baseadas na teoria da utilidade têm papel importante na avaliação econômica, principalmente em análises de custo-efetividade e custo-utilidade de intervenções relacionadas a diversas doenças e condições de saúde, como câncer infantil e sobrevivência. Alguns trabalhos desenvolvidos recentemente visam criar e aplicar medidas de qualidade de vida obtidas por meio da mensuração de preferências por estados de saúde, em grupos jovens, tais como crianças e adolescentes. A necessidade de utilização de respondentes substitutos é uma questão que permeia o uso dessas medidas nestes grupos, especialmente em crianças. Esta revisão apresenta uma avaliação crítica do uso de medidas de qualidade de vida associadas à saúde, obtidas por meio de preferências por estados de saúde, em países em desenvolvimento, com enfoque nas medidas denominadas Health Utilities Index, Mark 2 e Mark 3, comumente conhecidas como HUl2 e HUI3, e sua aplicação para sobreviventes de câncer na infância, na América Latina. Realiza-se uma discussão crítica do processo utilizado pelos pesquisadores quando empregam instrumentos já anteriormente traduzidos. A propriedade de outros instrumentos também é abordada, com ênfase nos atributos ou domínios abrangidos por cada medida analisada, para o câncer infantil. Espera-se que esta revisão beneficie futuros trabalhos na área de qualidade de vida associada à saúde, especialmente aqueles interessados no uso transcultural de medidas já existentes.

Palavras-chave: HUI2. HUI3. América Latina. Validação transcultural. Câncer infantil. Respondentes substitutos.

\section{Resumen}

Algunas consideraciones sobre el uso y la aplicación de medidas de calidad de vida asociada a la salud, con énfasis en estudios sobre sobrevivientes de cáncer en la infancia y adolescencia en países en desarrollo

En los países en desarrollo, como Estados Unidos, Canadá y Reino Unido, es cada vez mayor el empleo de instrumentos para medir la calidad de vida asociada a la salud. Estas medidas 
deben pasar por procesos de traducción, validación y adaptación cultural antes de ser utilizadas en países y/o idiomas diferentes a los de su origen. La utilización de instrumentos desarrollados en otros contextos culturales presenta varios desafíos, tales como la propiedad de la traducción, la adecuación de la adaptación cultural, así como un proceso de validación satisfactorio. Las preferencias por estados de salud basadas en la teoría de la utilidad tienen un rol importante en la evaluación económica, principalmente en el análisis de costo-eficacia y costo-utilidad de intervenciones relacionadas con diversas enfermedades y condiciones de salud, como el cáncer en la infancia y la supervivencia. Algunos trabajos desarrollados recientemente tienen como objetivo crear y aplicar medidas de calidad de vida obtenidas a través de la medición de preferencias por estados de salud, en grupos jóvenes, tales como niños y adolescentes. La necesidad de utilización de informantes sustitutos es un tema que traspasa el uso de estas medidas en estos grupos, especialmente en niños. Esta revisión presenta una evaluación crítica del uso de medidas de calidad de vida asociadas a la salud, obtenidas a través de las preferencias por estados de salud en países en desarrollo, con foco en las medidas denominadas Health Utilities Index, Mark 2 y Mark 3, comúnmente conocidas como HU12 y HU13, y su aplicación para sobrevivientes de cáncer en la infancia en América Latina. Se realiza una discusión crítica del proceso utilizado por los investigadores cuando emplean instrumentos anteriormente traducidos. También se plantea la propiedad de otros instrumentos, con énfasis en los atributos o dominios comprendidos por cada medida analizada para el cáncer en la infancia. Se espera que esta revisión sea beneficiosa para los futuros trabajos en el área de calidad de vida asociada a la salud, especialmente para los interesados en el uso transcultural de medidas ya existentes.

Palabras clave: HUI2. HUI3. América Latina. Validación transcultural. Cáncer en la infancia. Informantes sustitutos.

Recebido para publicação em 22/09/2009. Aceito para publicação em 03/11/2009. 
